\begin{tabular}{|l|l|l|l|l|}
\hline ACTA CARSOLOGICA & $32 / 1$ & 16 & $225-242$ & LJUBLJANA 2003 \\
\hline
\end{tabular}

COBISS: 1.01

\title{
DEVELOPMENT OF THE UNDERGROUND RAILWAY SYSTEM ON THE EXAMPLE OF POSTOJNSKA JAMA
}

\section{RAZVOJ JAMSKE ŽELEZNICE NA PRIMERU POSTOJNSKE JAME}

ALENKA ČUK ${ }^{1}$

\footnotetext{
${ }^{1}$ Notranjski muzej Postojna, Ljubljanska cesta 10, SI-6230 POSTOJNA, SLOVENIA e-mail: alenka.cuk@studioproteus.si
} 


\section{Alenka Čuk: Development of the underground railway system on the example of Postojnska jama}

The problem of making visits to Postojnska jama more comfortable and easier was solved in 1872 when the first railway was put in the cave. The path through the cave did not have many ascents or descents; therefore it was decided that the carriages in the cave could be "driven by manpower". After 1900 interest in visiting Postojnska jama increased. The Board of Postojnska jama constantly improved and "facilitated the cave traffic" and took care of the utmost comfort of the visitors. For all that, the small, manually operated railway was becoming less and less appropriate. The first test-drives with a locomotive were performed between April and June 1924. In April 1957 two new locomotives with batteries replaced the old, worn-out ones.

Key words: caves, railway, carriages "driven by manpower", locomotive, Slovenia, Postojnska jama.

\section{Izvleček}

UDK: 625.39:551.44(497.4 Postojna)“1872/2002”

\section{Alenka Čuk: Razvoj jamske železnice na primeru Postojnske jame}

Dolgoletno vprašanje udobnejšega in hkrati lažjega obiska Postojnske jame je bilo rešeno leta 1872, ko so po jami položili prve tire. Pot po jami ni imela ne velikih vzponov, niti ne velikih padcev, zato so se odločili da bo vozove po jami “človeška moč gonila”. Po letu 1900 je zanimanje za obisk Postojnske jame skokovito narastlo. Uprava Postojnske jame se je trudila izboljšati in "lajšati promet" v jami, poleg tega pa je, upoštevajoč želje in potrebe obiskovalcev, skrbela za vedno večje udobje slednjih. Kljub vsemu, pa mala ročna železnica ni več ustrezala potrebam tedanjih obiskovalcev. Prve poizkusne vožnje z lokomotivo so opravili med aprilom in junijem 1924. Aprila 1957 so pri Postojnski jami stare dotrajane lokomotive zamenjali z dvema novima, akumulatorskima.

Ključne besede: jame, železnica, jamski ročni voziček, lokomotiva, Slovenija, Postojnska jama. 
The beauty of Postojnska jama enchants every present day visitor from the very moment he enters through the magnificent entrance to the inner galleries of this cave, one of the first caves in the world to be opened to the public. The enthusiasm of the "first" visitors to the cave, who started coming in the $13^{\text {th }}$ century, must have been the same, although they could only see those parts of the cave close to the entrance. Until the beginning of the $19^{\text {th }}$ century the cave was open, unprotected and without any lighting or organized tours. The announcement of the second visit of the Emperor Franz I. in 1818, this time together with his wife Carla Augusta, was just the first in a series of events which has enabled over 29.000.000 visitors to see the Postojnska jama up to the present moment.

\section{SEDAN CHAIRS FOR THE EMPRESS AND HER LADIES-IN-WAITING}

When the railway that links Ljubljana and Trieste via Postojna was opened in 1857, access to the cave was easier and interest in it became even greater. The Emperor Franz Joseph and the Empress Elisabeth stopped in Postojna on the $11^{\text {th }}$ March 1857 on their way from Italy. The cave with its splendid lighting, its newly arranged pathways and widened passages and its new stylish decoration made for this particular occasion, was brilliant. Count Hohenwart with a team of engineers supervised by the district assistant governor in Postojna, Johann Arko, supervised all preparation work for this visit (Costa 1857, 86-87). In case the Empress and her ladies-in-waiting got tired (Franz Joseph and Elisabeth showed great interest in the cave, and stayed underground for more than two hours), they prepared three sedan chairs. The one for the Empress was covered with velvet (Savnik 1960, 103). But the noble visitors almost did not use them, since the Empress walked through most of the galleries (Costa 1857, 88). Later they were available for cave visitors (Shaw \& Čuk 2002, 19) but they were too expensive to be frequently hired.

\section{THE CARRIAGES IN THE CAVE WERE "DRIVEN BY MANPOWER”}

The problem of making visits to Postojnska jama more comfortable and easier was solved in 1872. On the initiative of the district governor in Postojna and President of the Cave Commission Anton Globočnik, the first railway was put in the cave. Thus, anyone who was tired from climbing the steps in Veliki dom (der große Dom) could visit the rest of the cave in a more comfortable way. As early as 1856 an unknown author of an article published in the Novice newspaper (Anon. 1856) suggested they improve "the 12 feet long path" between the monuments of the Emperors Ferdinand and Franz I, which would cost little but would bring great pleasure to the cave visitors. In this way the visitors would not have to "crawl" the first 84 steps to the bridge over the Pivka river and another 82 steps back into Veliki dom (Fig. 1). Moreover, they would avoid crossing the Pivka river, which frequently flooded the bridge during heavy rains and blocked the path. The very same year an artificial 1.5-metre-wide and 55-metre-long gallery was cut into a steep wall over the river. The gallery linked Veliki dom with Stara jama (The Old Cave), which was at the time called the Emperor Ferdinand's Cave.

At the beginning of 1872 the Cave Commission decided to put rail tracks into the cave as far as the foot of Kalvarija (der Kalvarienberg) (Anon. 1872a) (Fig. 2). The entrance station was at 


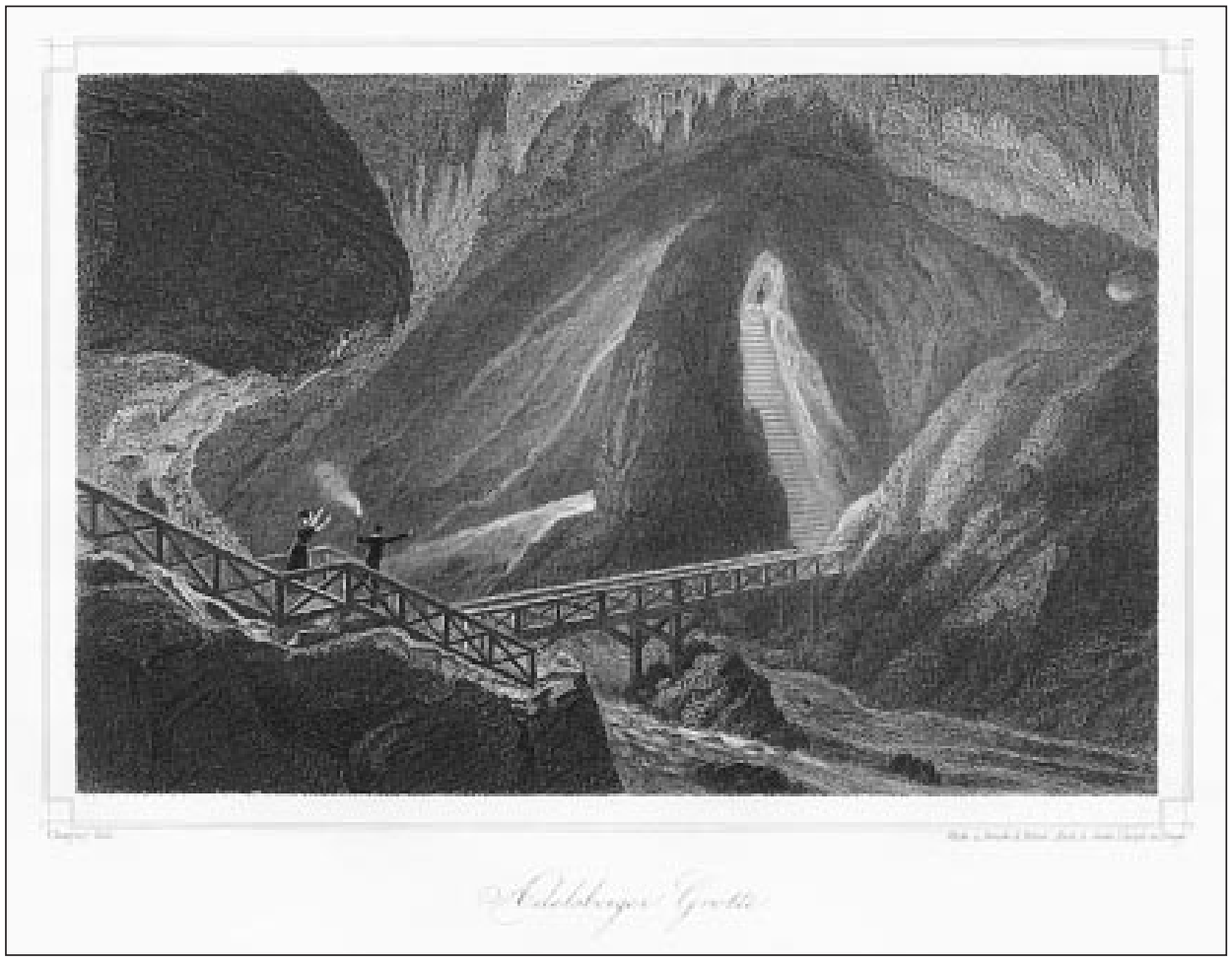

Fig. 1: The wooden bridge over the underground river Pivka in Veliki dom in Postojnska jama, steelengraving by Nicolas Marie Joseph Chapuy, 1856 (Notranjski muzej Postojna collection).

the dripstone called Prižnica on the other side of Veliki dom (Sajevic 1972, 7), since it was impossible to build the railway over Veliki dom due to the nature of the ground. The intended length of the cave railway was 2260 metres (Lapajne 1907, 19). Work supervised by engineer Gregor Oblak, began at the end of February 1872 and lasted for approximately three months (Anon. 1872b). A fairly critical author of an article in the newspaper Soča (Anon. 1872c) wrote about a traditional Pentecost celebration $\left(20^{\text {th }}\right.$ May) (Harvey 1946, 925, 928) in the cave, which at the time hosted "from five to six thousand visitors, excluding the local visitors" and mentioned that the cave railway could be seen in the cave. However, the underground train did not operate, as it was highly impractical, according to the author of the article, especially on such occasions of mass visits. If the underground train had been used, there would have been too little room for the pedestrians and moreover an accident might have happened due to the crowd.

The path through the cave did not have many ascents or descents; therefore it was decided that the carriages in the cave could be "driven by manpower" (Fig. 3). The part of the cave the visitors walked through for half an hour could from then on be seen in "five minutes" from the elegant double-seated carriages called "faetons" (Anon. 1872a). This first underground railway in 


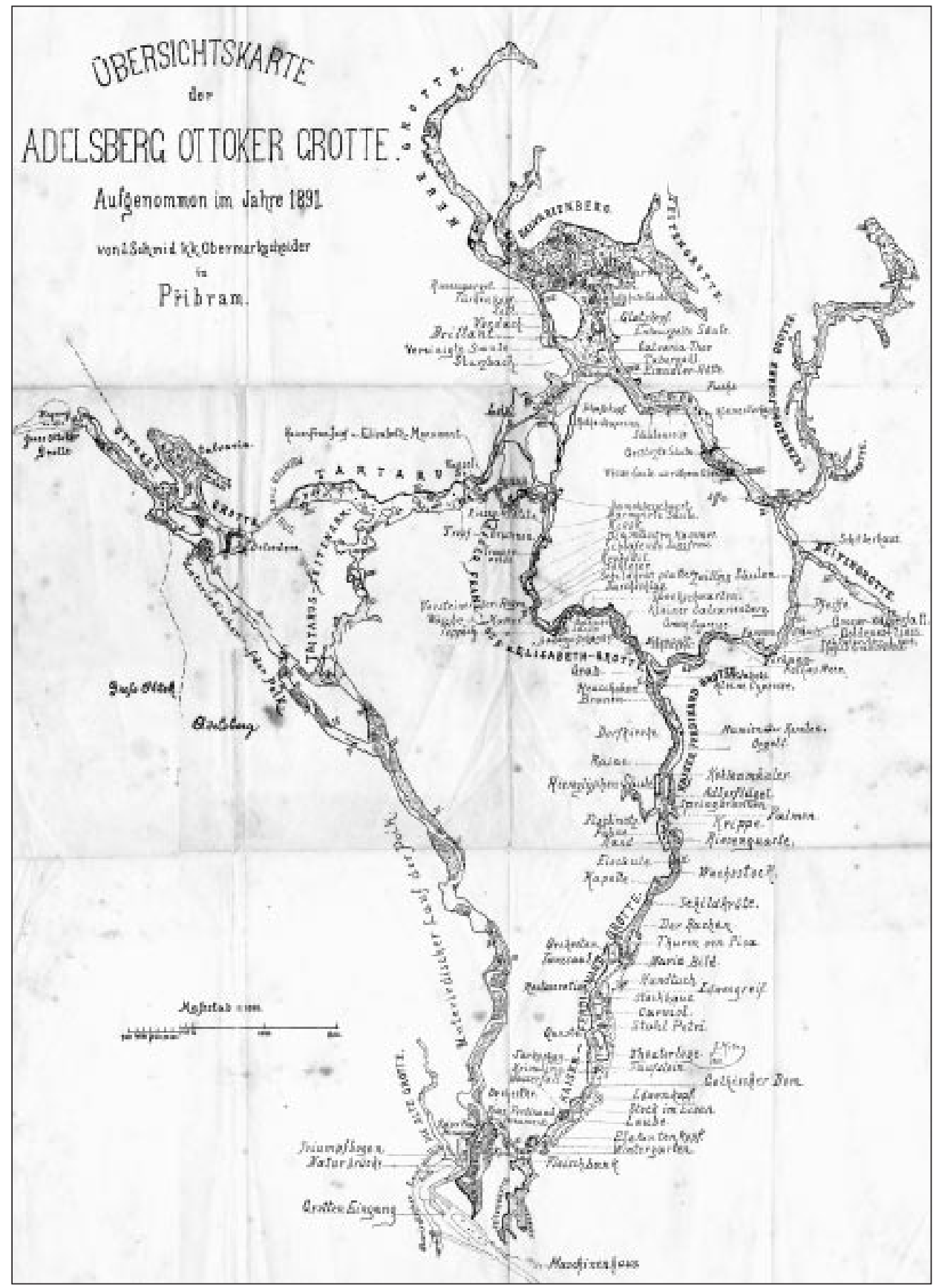

Fig. 2: The railway line from the far side of Veliki dom to the foot of Kalvarija, shown on Joseph Schmid's plan of 1891 (Notranjski muzej Postojna collection). 


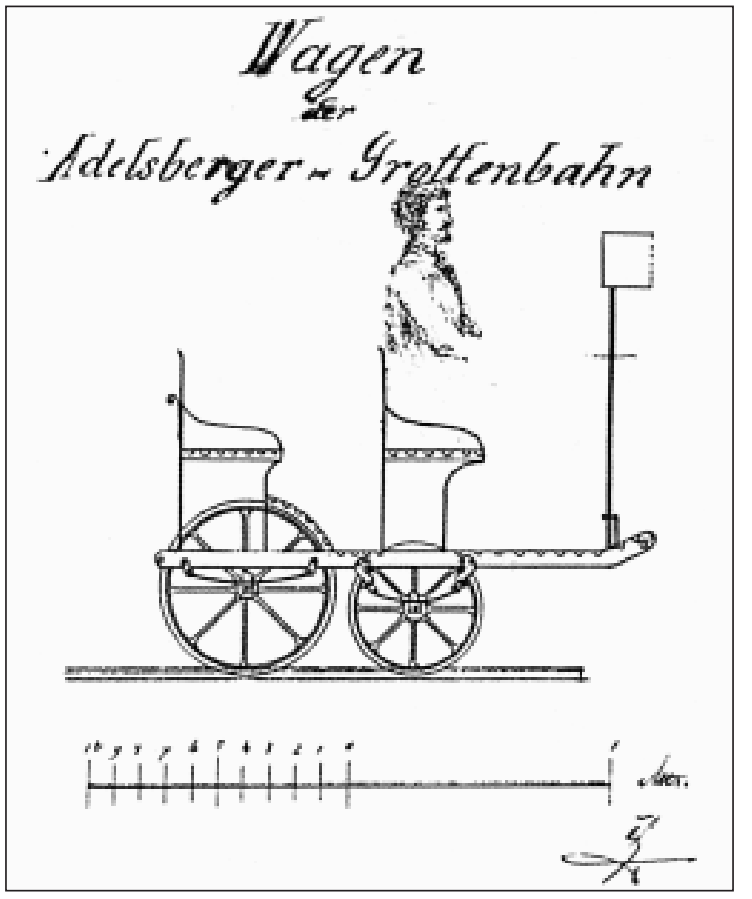

Fig. 3: A design of 1876 for a twoseat passenger trolley (Postojnska jama archives, in Inštitut za raziskovanje krasa, Postojna).

the world started operating on $16^{\text {th }}$ June 1872. The visitors could use the carriages (Fig. 4) in one direction or both directions, into and out of the cave. The return ticket cost 1 florin, while the visitors paid 70 kreutzers for a single ticket (Savnik 1960, 107). The price was quite high and therefore only a few visitors used this miniature underground railway. The Emperor Franz Joseph was taken into the cave on the carriage on his second visit to the Postojnska jama in July 1883 together with the district governor Anton Globočnik. First

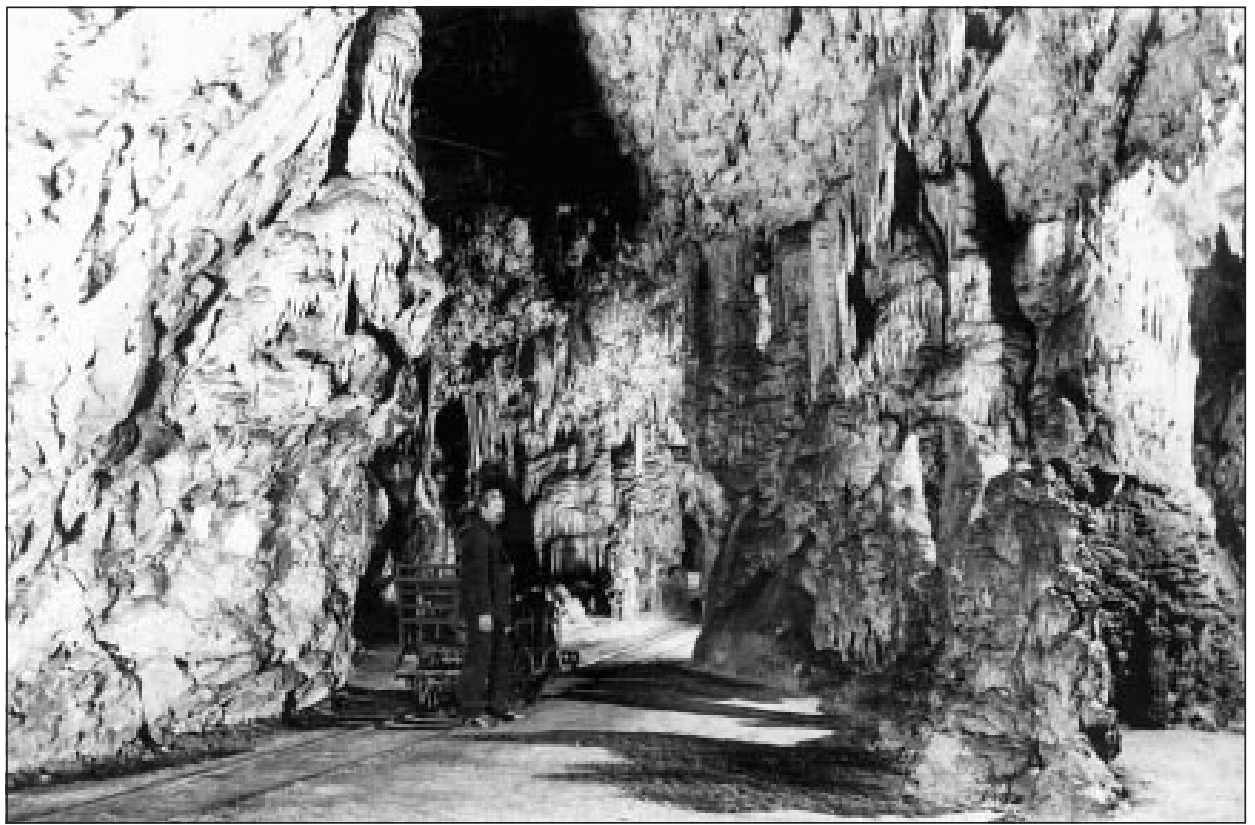

Fig. 4: Cave guide by the carriage "faeton" after 1900 (Notranjski muzej Postojna collection). 
they were shown the brightly lit Plesna dvorana (der Tanzsaal). After a short stop, Globočnik, Franz Joseph, his most important assistant officials and baron Winkler continued the visit up to Kalvarija, which was, like Veliki dom, illuminated with electric bulbs (Anon. 1883).

Many newspaper articles and reports published after 1900 show increased interest in Postojnska jama and a dramatic rise in the number of its visitors. At the beginning of the $20^{\text {th }}$ century, the number of visitors in a year exceeded the magic figure of 10.000 (in 1901 there were 10.876 visitors to the cave). In 1905 the President of the Postojnska jama Board [Štefan Lapajne] proudly declared that the "official report" ([Lapajne], 1905, 3, 5, 6), which "comes to light" in this form for the first time, taking into account the official data, gives a clear picture of the Board's activity and simultaneously demonstrates a sharp increase in the number of visitors to the cave in 1904 . The report also shows the efforts of the Board constantly to improve and "facilitate the cave traffic" and take care of the utmost comfort of the visitors to the cave. In 1905 there were 6482 individual visitors, while mass visits (including visits from various associations, institutes, schools, visitors to the cave Pentecost celebration and the summer celebration in August) brought as many as 14.345 visitors to the cave, not counting local people who visited the cave free of charge. Almost a decade later an unknown author wrote about the enormous number of visitors to the cave in his article "A huge number of visitors to the Postojnska jama" published in the newspaper Slovenec (Anon. 1913). The number of visitors was outstanding even for the present-day working conditions, a circular railway line and a better fleet of carriages. Numerous trains from different destinations such as Venezia (960), Wien (846), Opatija (1200), Trieste (1920), Klagenfurt (670), Rijeka (1100), Pula (590) and Ljubljana (962), brought more than 11.000 visitors to the summer celebration in Postojnska jama. The author of the article wrote: "In the underground galleries there were crowds and you could barely move forwards. The atmosphere was excellent due to the fabulous illumination, music, exquisite restaurant and café. The cave post office was very busy since 50.000 postcards were posted on that day. The careful and diligent promotion that reached every corner of our monarchy, was extremely effective, which is proved by the huge number of visitors to the cave. This success is undoubtedly the merit of the enormous efforts of the keeper Andrej Perko..."

\section{MOTOR-DRIVEN CARRIAGES}

The small, manually operated railway was becoming less and less appropriate due to the huge number of visitors. The above-mentioned and similar articles may have encouraged the Cave Board to start thinking about motor-driven carriages. In 1914 they contacted the factory Orenstein \& Koppel and ordered a locomotive called "Montania" with a petrol engine, usually used in mines, and carriages with four seats (Borjančič 1992, 12). Those optimistic plans were interrupted by the outbreak of the First World War. Nevertheless, the Italians started work in the cave and continued it in the 1920s. In a letter by an unknown author (Postumia, 1921) entitled "Un complesso piano di lavori", it is reported that the first part of the cave is already equipped with a railway system and that new material for this railway is still at the manufacturer in Praha, although the Cave Board owns it. The same Italian author explains in the above-mentioned letter that quite a lot of work is to be done within the shortest time possible; delivery of the prepaid material, completing of the rail system in the cave, modernization of the cave electrical system, 
removal of the monuments "praising Austrian emperors", replacing Slovenian and Austrian "infantile names of the dripstones" with the names from Roman mythology and employing foreign language speaking guides.

The plan for the final arrangement of the reopening of the cave after World War I to the public (Postumia, 1922) includes the tourist path through the cave and suggests four different parts. The first part leads from the cave entrance to Razpotje (das Grab), the second from Razpotje to Kalvarija, the third part is a circular path round Kalvarija and the forth part leads back from Kalvarija to Razpotje. Two of the above-mentioned parts of the cave were suitable for rail transport. The old underground railway dating from 1872 was useless because humidity had decayed the woodwork. Although the locomotive and carriages were already in the cave, the authors of the plan suggested their replacement. The complete underground railway system, from the cave entrance to Kalvarija was restored in 1923 (they replaced 2700 sleepers) (Anon. 1925a). Between April and June 1924 the first test-drives were performed with the locomotive called "Montania" no. 803 (Fig. 5), with one-cylinder water-cooled 6-8 BHP petrol engine (Anon. 1924a, b). One of the first noble visitors, who used the underground railway from the cave entrance to Plesna dvorana at the end of May 1923, was Shri Vijayadevji Mohandjevi, maharaja of Dharampur with his wife and his personal doctor (Anon. 1924c). On 2 ${ }^{\text {nd }}$ August 1924 (Anon. 1924d) the new underground railway was officially opened. The locomotive "Montania" hauled five four-seated carriages into the cave four times a day (at 10 a.m., at noon and at 2 and 4 p.m.). In July 1925 Cremona Nuova

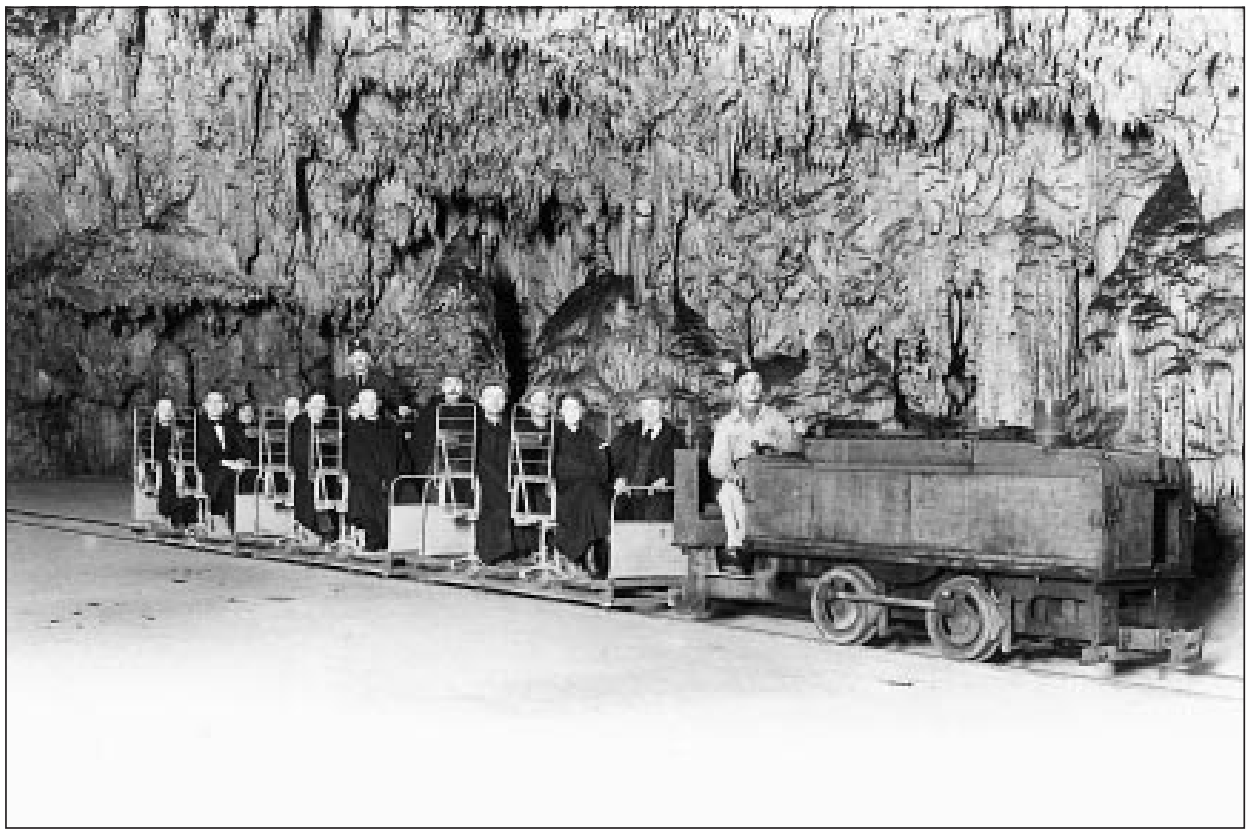

Fig. 5: One of the runs of the unique train with the locomotive "Montania" after August 1924 (Notranjski muzej Postojna collection). 
(Anon. 1925b) wrote: "The big rush on the Lilliputian train considerably embarrassed the Cave Board. Naturally, they expected great interest in the underground railway but nobody could have anticipated people pushing each other and even crying."

\section{PLANS OF THE CAVE DIRECTOR IVAN ANDREJ PERKO}

The Cave Board accepted the plans presented by the director of the cave Ivan Andrej Perko to meet the desires and needs of the visitors and thoroughly reconstructed and modernized the underground railway during the winter of 1924/25. The work lasted for five months and was done by two teams. One team was widening Veliki dom and levelling the ground for the railway (Fig. 6) while the other was digging a carriage garage into the rock (Fig. 7). They widened the cave entrance together with the path into the cave, which crossed the natural bridge ( $2.8 \mathrm{~m}$ before, $5.5 \mathrm{~m}$ after). They built the lookout platform over the river and thus enabled the tourists to see the underground river Pivka. 30 tons of concrete and 4.5 tons of iron were used to build the reinforced concrete bridge and they also provided $408 \mathrm{~m}$ of new hand rails. I. A. Perko drew all plans and work was finished without any accident or disturbing of the schedule of visits to the cave.

At the same time they refurbished the platform in front of the cave entrance. A forty-metre long concrete wall separated the upper part of the platform, with the railway leading to the coach

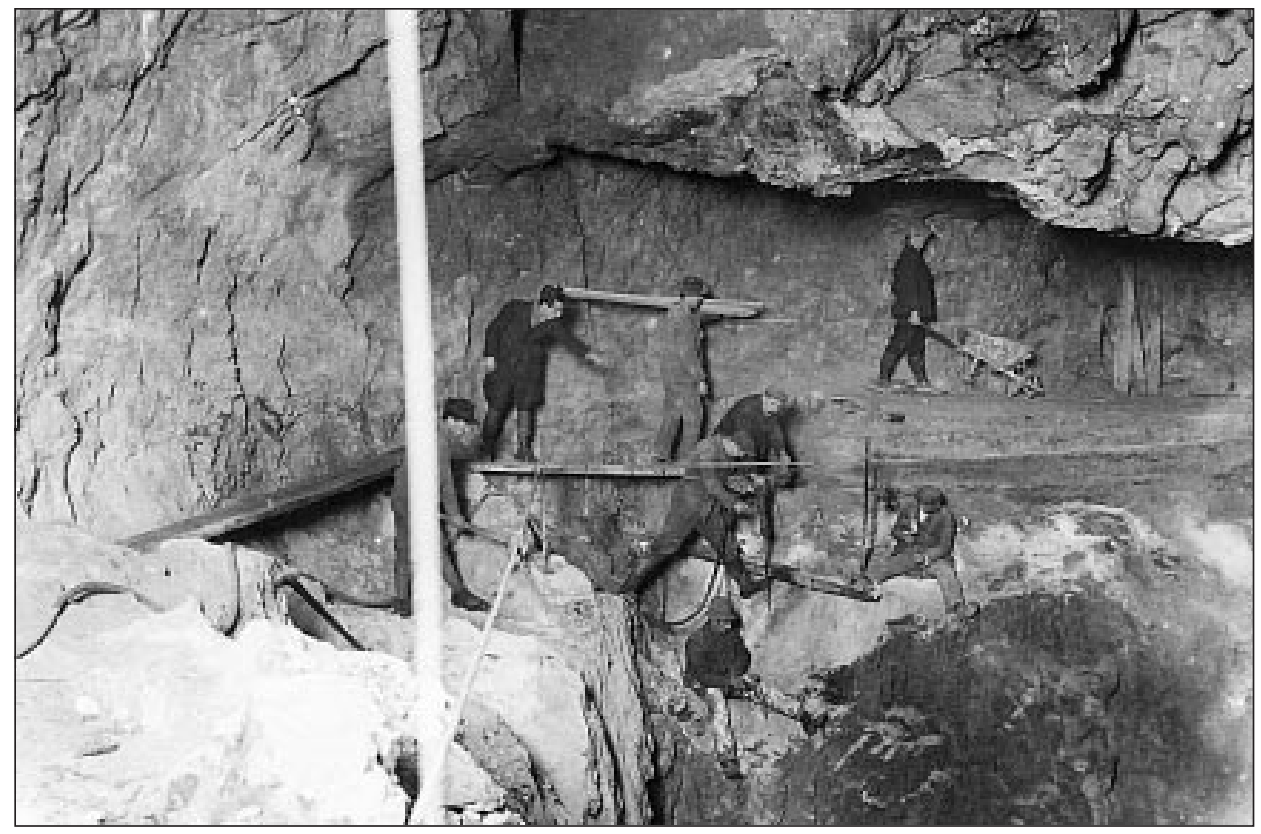

Fig. 6: Widening of Veliki dom and levelling the ground for the railway, winter of 1924/25 (Notranjski muzej Postojna collection). 


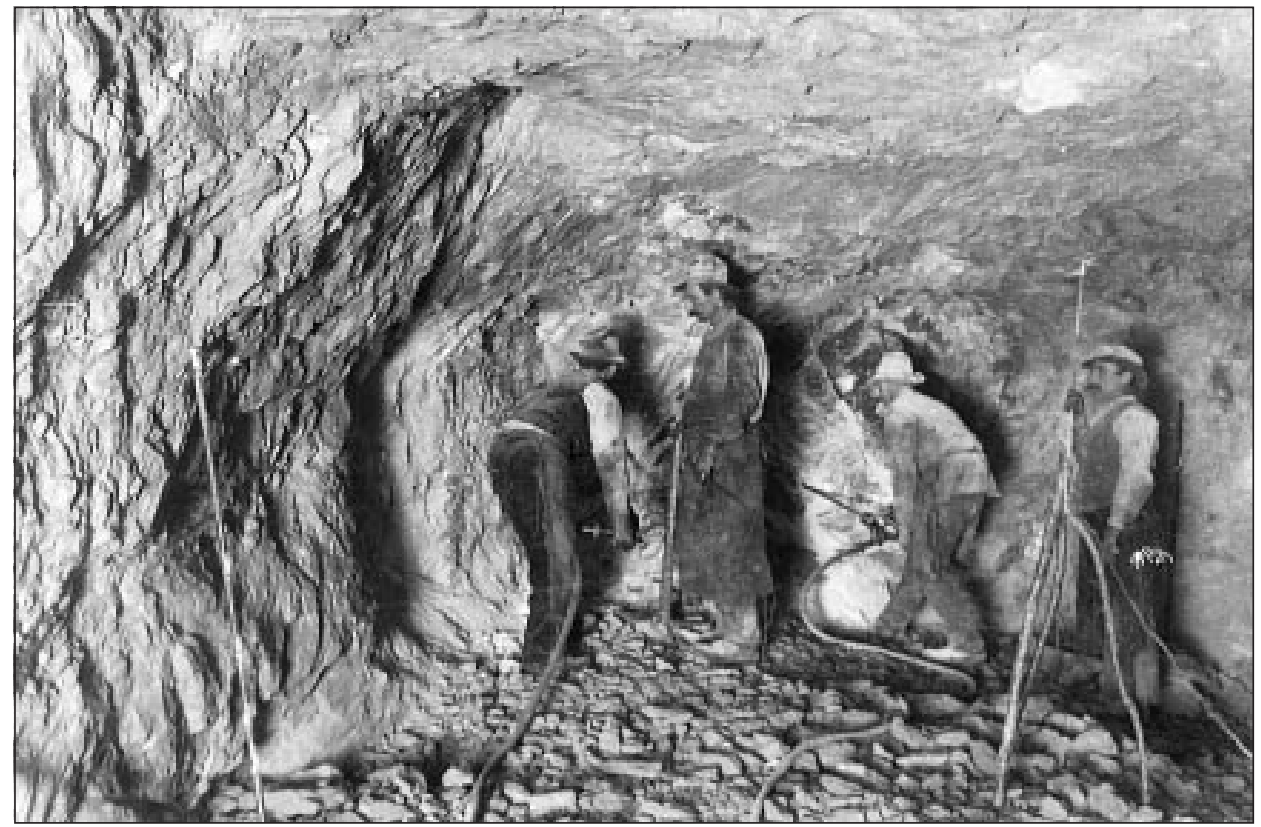

Fig. 7: Digging a carriage garage into the rock, winter of 1924/25 (Notranjski muzej Postojna collection).

garage, from the lower part of the platform. The upper part boasted the cave administration offices and three kiosks, where visitors could borrow capes or leave their luggage or even buy drinks and snacks and of course the tickets for the cave tour. While digging the artificial gallery, which served as the carriage garage and was equipped with double rail track and a side gallery in which they kept petrol, oil and cave equipment, the workers removed $324 \mathrm{~m}^{3}$ of material (Bertarelli 1925, 625-632).

They also had to plan the purchase of new locomotives. On $27^{\text {th }}$ March 1925 (Roma 1925) Orenstein \& Koppel (Fig. 8) sent from their factory in Nordhausen, a new ("Montania", S-10, no. 2044) and more powerful petrol-driven locomotive with three axles while the previous one had only two. They also bought the corresponding carriages with six adjustable seats. A year later, in July 1926 (Milano 1926) they bought the third 20 BHP petrol-driven locomotive produced in Milano "Cemsa", type 20 G, no. 20-779) (Anon. 1926). Three trains with a total of 31 carriages took the tourists into the cave eight times each day. The journalist of a newspaper $I l$ resto del Carlino (Anon. 1925c) from Bologna, experienced the cave tour with the miniature underground railway himself and wrote about his impressions: "It is 4 p.m. The train stops on the platform in front of the cave (Fig. 9), having passed through "Simplon", as they humorously call 75-metre long gallery, acting as the underground railway station. The tourists get on the train and the responsible guide rings the bell to announce the departure of the train. Those who decided to visit the cave on foot, follow the guides. There are some elderly people and quite a lot of ladies and young ladies on the train (the journalist was sitting behind them). The train slowly reaches Razpotje 


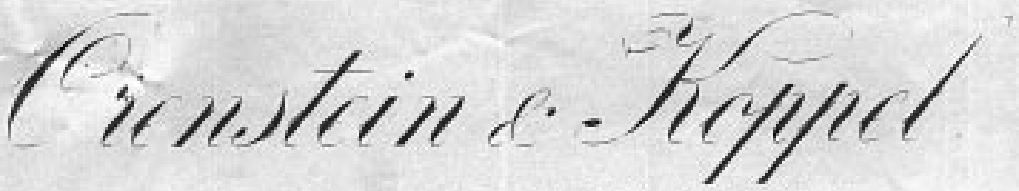

FERROVIE PORTATILI E FISSE

MILANO(2)

VIa SIL PELOLCO,12

Carela Ponaig 664

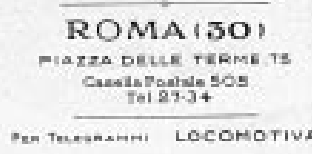

SESTO S GIOVANNI

TADEFICA

VIALE ITAUA 93

nsens vis youmen.

Ord. 3025

Roma.ı30 I5 Apr110 I9P5

Spett. R.R. GROTIS DI POBTULIA

P O 0 \&

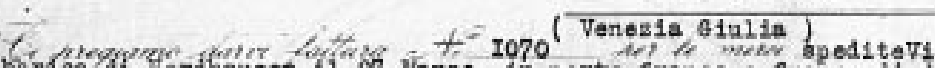

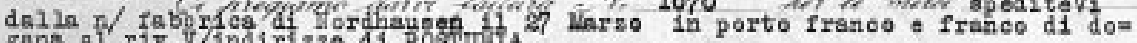

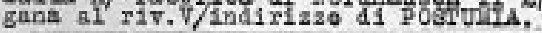

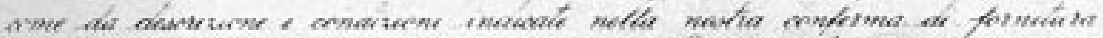

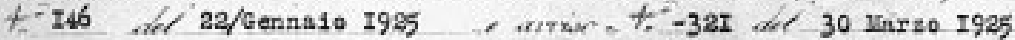

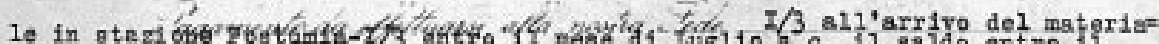

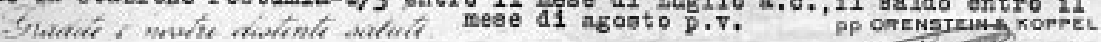

man-men-

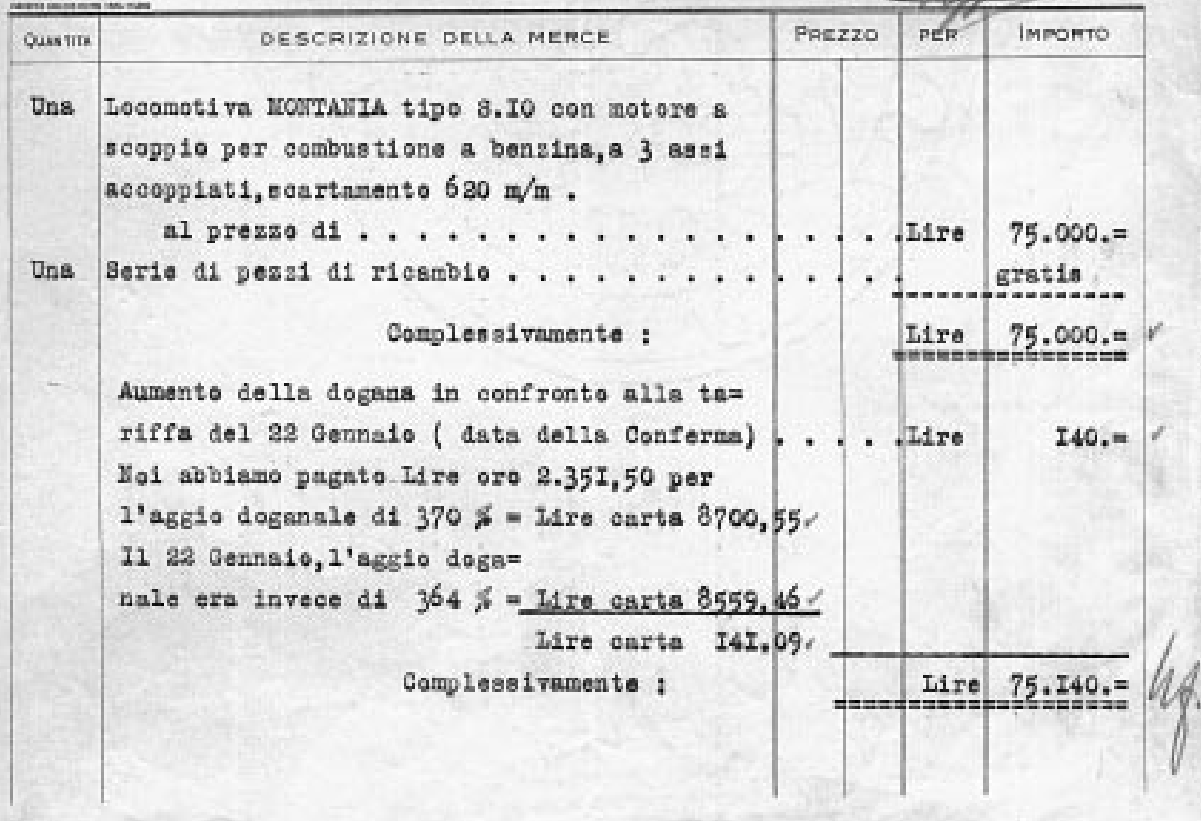

Fig. 8: Bill for the locomotive "Montania" S-10 of 15 April 1925 (Postojnska jama archives, at Inštitut za raziskovanje krasa, Postojna). 


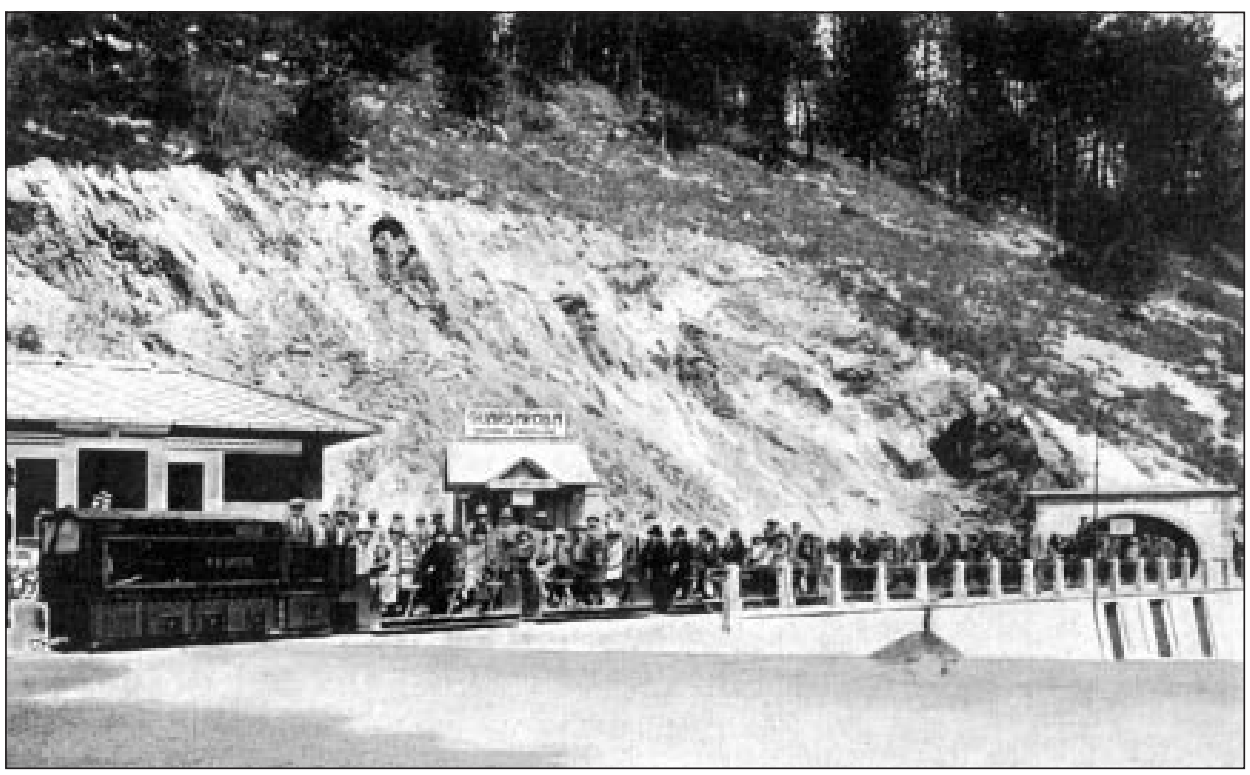

Fig. 9: The train on the platform in front of the cave after March 1925 (Notranjski muzej Postojna collection).

where the visitors get off the train and continue their visit on foot through the galleries of Male jame ...", up to Koncertna dvorana (The Concert Hall) and to the foot of Kalvarija. There they joined the visitors who reached Kalvarija (the final railway station with the turning point for the locomotives) by train. The train waited for the visitors at the foot of Kalvarija and took them back towards the cave entrance using the same way as before. On its way through the cave (approximately 5 kilometres in total) the train stopped only once, by the old post office close to Plesna dvorana, where the visitors posted their postcards during a ten-minute break (Anon. 1925d).

In 1928 there were significant changes to the entrance of the cave for the last time when the headquarters, the entrance platform with the railway station and the reception area were built by a building company from Trieste called Ghira e Pollaco. The architect Pietro Palumbo drew the plans for the building with the offices, reception area and restaurant (Anon. 1929, 10-11).

A new, visitor-friendly railway station with two tracks and a raised platform, which offered safer and more comfortable access into the cave, was located between the headquarters and the rock cliff. That was the entrance for the visitors who wanted to see the cave from the underground train, while those who wanted to visit it on foot entered through the main entrance. The visitors could choose between visiting the cave with the underground train and on foot or walking all the way through the cave until 1963. After that year all visitors used the underground train. 


\section{NEW LOCOMOTIVES WITH BATTERIES AND A CIRCULAR LINE THROUGH THE CAVE}

In the 1950s the cave transport could barely meet the needs of modern tourism. Moreover, exhaust fumes from the locomotives fogged up the cave, diminished visibility and caused an unpleasant odour. The newspaper Slovenski Jadran (B. K. 1957) reported that the over thirty-year old locomotives "were asthmatic" and they might disappoint the visitors by breaking down in the cave. On $6^{\text {th }}$ April 1957 two new locomotives with batteries ("Emam" Segrate Milano, T 50) (Fig. 10) replaced the old, worn-out ones on the occasion of the grand opening of the tourist season (Anon. 1957). An insulated and completely dry battery-charging garage was built in the gallery which had been used as the entrance to the cave from 1819 to 1866 . They bought two more locomotives and in 1964 three underground trains could take 2160 visitors into the cave daily. A single-track railway with only two passing places along the whole railway, which allowed only three locomotives to be used at a time, became a real bottleneck and, moreover, the procedure of changing the locomotives under Kalvarija took around 20 minutes. Therefore, The

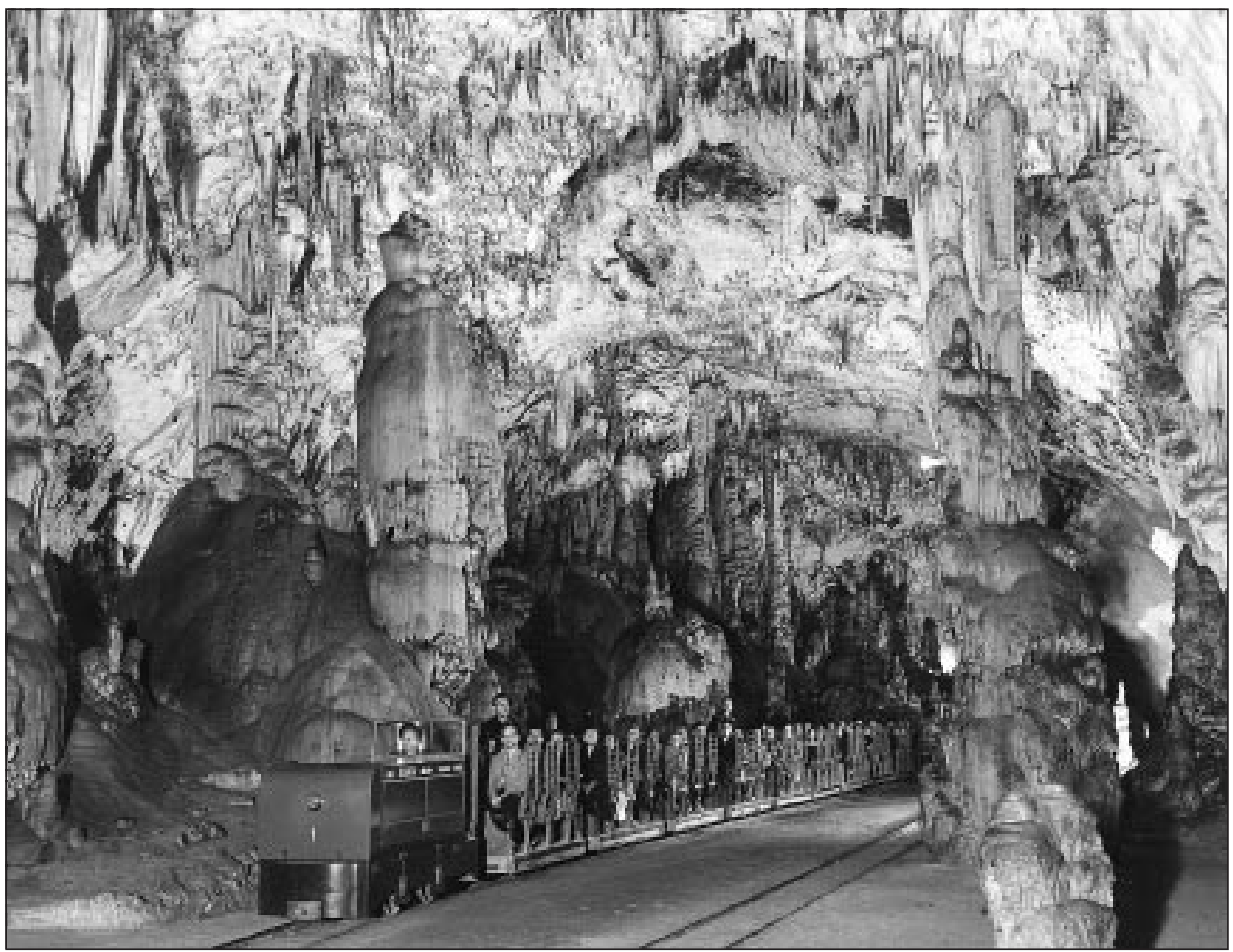

Fig. 10: "Emam” Segrate Milano, T 50 locomotive with batteries, after April 1957 (Notranjski muzej Postojna collection). 


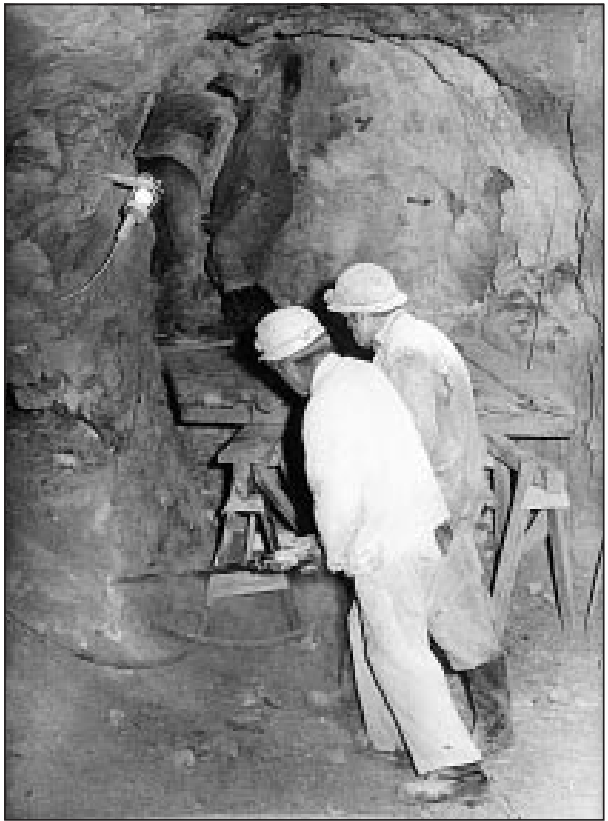

Fig. 11: Works for a double-track circular line in the cave, $1^{\text {st }}$ phase (Notranjski muzej Postojna collection).

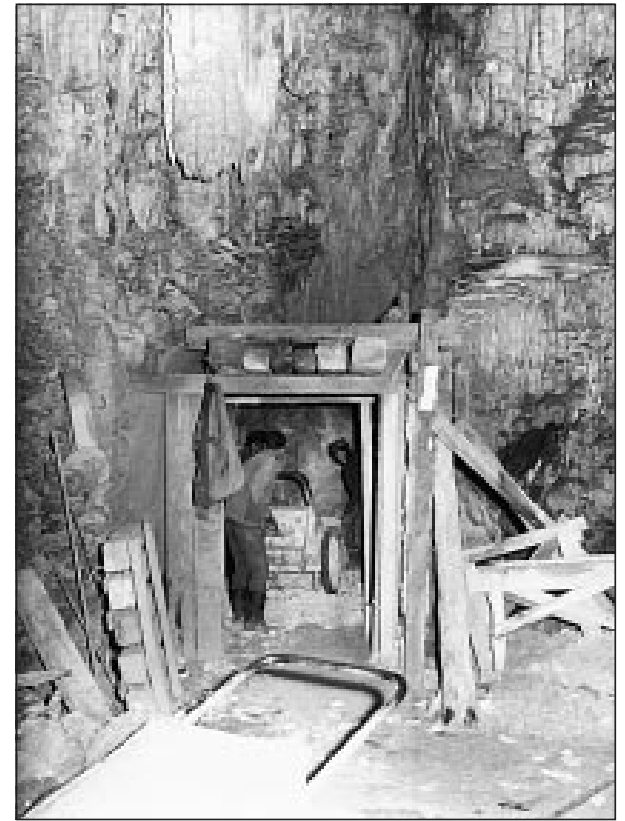

Fig. 12: Works for a double-track circular line in the cave, $2^{\text {nd }}$ phase, 1967 (Notranjski muzej Postojna collection).

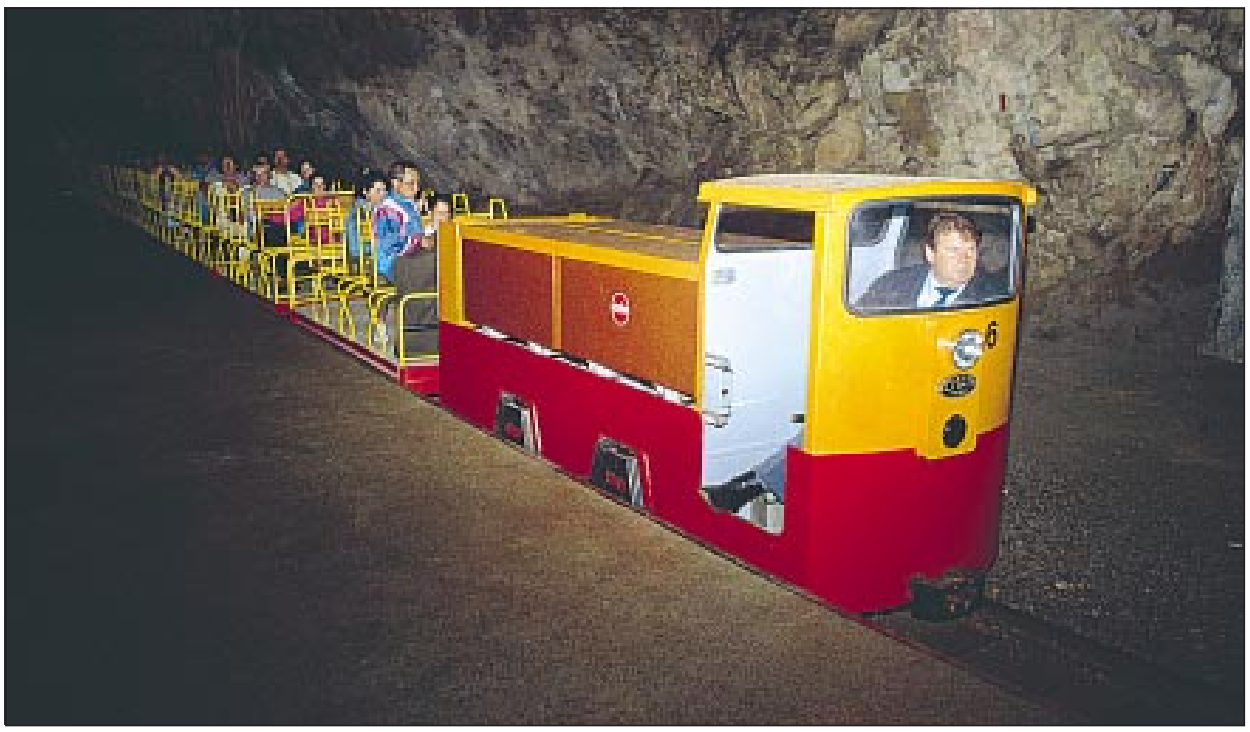

Fig. 13: The ride by train ends below Kalvarija and visitors gather around guides speaking diverse languages, starting off from here for a closer inspection of the cave, 1992 (Notranjski muzej Postojna collection). 
Postojnska jama authorities considered the possibility of more frequent departures of the underground train. This brought to light the need for another rail track in the cave and new underground trains. In 1959 they ordered the plans for a double-track circular line in the cave as well as the plans for a new coach garage at the Projektivni atelje in Ljubljana. They presented various solutions. However, priority was given to the one which revealed the most beautiful parts of the cave to the visitors without damaging the natural attractions (Fig. 11). In April 1964 (Anon. 1964) the first part of the new railway was built through the cave galleries, up to the foot of Kalvarija. In 1968 the second phase was finished with the circular line in Koncertna dvorana (Sajevic 1972, 8) (Fig. 12). Present-day visitors still use the underground railway station in Koncertna dvorana to get on the train which takes them out of the cave. Today, 130 years after the first double-seated carriages pushed by the cave guides were introduced into the cave in order to make the tour more comfortable for the visitors, there are ten sophisticated locomotives using batteries (Fig. 13) and six sets of carriages, two modern railway stations, one at the entrance of the cave and the other in Koncertna dvorana, and a circular railway line equipped with all the necessary signals.

\section{ACKNOWLEDGMENTS}

I am grateful to Trevor $R$. Shaw who read through several drafts of the paper, located material and made many useful suggestions and to Nadja Adam who helped to collect information from newspapers, did much useful searching of archive files and photodocumentation and translated Italian newspaper and archive articles which provided dates and other important information.

\section{REFERENCES}

Anon. 1856: Novice, 14 May, Ljubljana.

Anon. 1872a: Slovenski narod, 27 April, Ljubljana.

Anon. 1872b: Novice, 28 February, Ljubljana.

Anon. 1872c: Soča, 1 June, Gorica.

Anon. 1883: Edinost, 18 July, Trieste.

Anon. 1913: Slovenec, 3 August, Ljubljana.

Anon. 1924a: Il Popolo, 23 April, Roma.

Anon. 1924b: Il Sole, 23 May, Milano.

Anon. 1924c: L'Italia, 18 June, Chicago.

Anon. 1924d: Gazzetta Ferrarese, 7 August, Ferrara.

Anon. 1925a: Relazione della Commissione alle loro Eccelenze i ministri dell' economia nazionale e delle finanze sull'andamento dell'azienda durante l'esercizio 1924-1925.- Reale Commissione Amministratice delle Grotte Demaniali di Postumia, 1-24, Trieste.

Anon. 1925b: Cremona Nuova, 17 July, Cremona.

Anon. 1925c: Il resto del Carlino, 27 June, Bologna.

Anon. 1925d: Il Popolo d'Italia, 23 August, Milano.

Anon. 1926: Relazione della Reale Commissione alle loro Eccelenze i ministri dell' economia 
nazionale e delle finanze sull'andamento dell'azienda durante l' esercizio 1925-1926.Reale Commissione Amministratice delle Grotte Demaniali di Postumia, 1-24, Trieste.

Anon. 1929: Relazione dell Consiglio d'Amministrazione alle loro Eccelenze i ministri dell' economia nazionale e delle finanze sull' andamento dell' azienda dal $1^{\circ}$ gennaio al 31 dicembre 1928.- RR. Grotte Demaniali di Postumia, Amministrazione autonoma di Stato, 1-35, Postumia.

Anon. 1957: Slovenski Jadran, 12 April, Koper.

Anon. 1964: Delo, 16 March, Ljubljana.

Bertarelli, L.V., 1925: Novità di Postumia, Le Vie d'Italia, 31, (6), 625-632, Milano.

Borjančič, A., 1992: 120 let železnice v Postojnski jami 1872 - 1992.- Notranjski kompleksni muzej, p. 40, Postojna.

B. K., 1957: Slovenski Jadran, 15 March, Koper.

Cemsa, 1926: Bill dated 14 July 1926 from "Cemsa", Società per costruzioni elettromeccaniche di Saronno, Milano. (Postojnska jama archives, at Inštitut za raziskovanje krasa, Postojna).

Costa, E. H., 1857: Denkbuch der Unwesenheit Allerhöchstihrer Majestäten Franz Josef und Elisabeth im Herzogthume Krain.- Kleinmayr \& Bamberg, p. 140, 1xxi, Laibach.

Harvey, P., 1946: The Oxford Companion to English Literature, $3^{\text {rd }}$ edn.- Clarendon Press, p. viii, 932, Oxford.

[Lapajne, Š.], 1905: Upravno poročilo upraviteljstva Postojnske jame za leto 1904.- Upravna komisija Postojnske jame, p. 20, Postojna.

Lapajne, Š., [1907]: Aus der Chronik der Adelsberger Grotte.- Kleinmayr \& Bamberg, p. 62, Laibach.

Postumia, 1921: Un complesso piano di lavori (letter dated 9 March, Postojnska jama archives, in Inštitut za raziskovanje krasa, Postojna).

Postumia, 1922: Programma di lavoro per la definitiva sistemazione delle Grotte Demaniali di Postumia, (report dated 7 August; Postojnska jama archives, at Inštitut za raziskovanje krasa, Postojna).

Roma, 1925: Bill dated 15 April from Orenstein \& Koppel, Ferrovie portatili e fisse. (Postojnska jama archives, at Inštitut za raziskovanje krasa, Postojna).

Sajevic, J., 1972: Proteus Anguinus, October, (5), p. 7-8, Postojna.

Savnik, R., 1960: Iz zgodovine Postojnske jame II.- Kronika, 8, (2), 99-110, Ljubljana.

Shaw, T. R. \& A. Čuk, 2002: Royal and other noble visitors to Postojnska jama 1819 - 1945.Acta Carsologica 31 (1), supplementum I, p. 106, Ljubljana.

\section{RAZVOJ JAMSKE ŽELEZNICE NA PRIMERU POSTOJNSKE JAME}

\section{Povzetek}

Z otvoritvijo Južne železnice (1857), ki je Ljubljano preko Postojne povezala s Trstom, je Postojnska jama postala dostopnejša in zanimanje zanjo se je še povečalo. 11. marca 1857 se je na poti iz Italije v Postojni ustavil cesarski par, Franc Jožef in Elizabeta. Za cesarico in njene dvorne dame so v primeru, da bi jih pešpot po jami utrudila, pripravili tri nosilnice. Vendar jih skorajda niso uporabile, saj je cesarica večji del jame prehodila. Kasneje so bile nosilnice za 
določeno plačilo na voljo obiskovalcem jame, a se jih zaradi dokaj visoke cene niso ravno pogosto posluževali.

Dolgoletno vprašanje lažjega in udobnejšega obiska Postojnske jame je bilo rešeno leta 1872. $\mathrm{V}$ tem letu so na pobudo postojnskega okrajnega glavarja in predsednika Jamske komisije Antona Globočnika položili prve tire po jami. V začetku leta 1872 se je Jamska komisija odločila speljati tire vse do vznožja Kalvarije. Vstopna postaja je bila šele pri kapniški tvorbi imenovani "Prižnica", ker je zaradi konfiguracije terena preko Velikega doma niso mogli speljati. Tire v dolžini 2260 metrov so začeli postavljati konec februarja 1872, dela v jami pa so trajala približno tri mesece. Nekoliko kritičen avtor prispevka v časopisu Soča je ob poročanju o tradicionalni binkoštni veselici v jami, katere se je tega leta udeležilo "od 5 do 6000 samo zunanjih obiskovalcev" omenil, da je v jami opaziti tire za železnico. Slednja ni vozila, saj je po besedah pisca, zlasti ob tako množičnih obiskih, nepraktična. Če bi nekateri uporabili železnico, bi zmanjkalo prostora za pešce, v gneči pa bi se utegnila zgoditi tudi kakšna nesreča, je menil.

Pot po jami ni imela ne velikih vzponov, niti ne velikih padcev, zato so se odločili da bo vozove po jami "lahko človeška moč gonila". Prva podzemeljska železnica na svetu je tako stekla 16. junija 1872. Obiskovalec se je v jamo lahko peljal v eno ali pa v obe smeri, seveda za različno ceno.

Iz mnogih časopisnih člankov in poročil po letu 1900 lahko razberemo kako se je večalo zanimanje za Postojnsko jamo, oziroma kako skokovito je naraščalo število njenih obiskovalcev. V začetku 20. stoletja je število obiskovalcev prvič preseglo takrat magičnih 10.000. Mala ročna železnica je ob tako povečanem obisku postajala iz leta v leto bolj neuporabna. Jamska uprava je, morda tudi na podlagi zgoraj omenjenega in podobnih člankov, začela razmišljati o motorni vleki. Leta 1914 so v tovarni Orenstein \& Koppel naročili rudniško lokomotivo "Montania” z bencinskim motorjem ter štirisedežne vagončke. Izpeljavo optimistično zastavljenih načrtov je onemogočila prva svetovna vojna, a Italijani so z deli začetimi med vojno nadaljevali v dvajsetih letih preteklega stoletja. Stari, leta 1872 nameščeni tiri so bili neuporabni, saj so zgnili. Celoten železniški sistem od vhoda v jamo do Kalvarije (zamenjali so kar 2700 prečnih pragov) so obnovili leta 1923. Med aprilom in junijem 1924 so z lokomotivo "Montania" št. 803, z enovaljnim bencinskim motorjem na vodno hlajenje in močjo 6-8 HP, opravili prve poskusne vožnje. Kot eden prvih odličnejših gostov se je na ogled z novim jamskim vlakom od vhoda do Plesne dvorane konec maja popeljal Shri Vijayadevji Mohandjevi, maharadža Dharampurja, z ženo in svojim osebnim zdravnikom. 2. avgusta 1924 je uradno stekel promet po na novo urejeni progi. Lokomotiva "Montania" je pet štirisedežnih vagončkov popeljala v jamo štirikrat dnevno (ob 10.00, 12.00, 14.00 in 16.00 uri). Jamska uprava je, z namenom zadostiti željam oziroma potrebam obiskovalcev, sprejela načrte Ivana Andreja Perka, takratnega direktorja Postojnske jame, in v zimski sezoni 1924/25 temeljito rekonstruirala oziroma posodobila železniško progo v jami. Dela, ki so trajala pet mesecev, sta opravili dve ekipi. Ena je širila Veliki dom in nivelirala progo, druga ekipa pa je v živo skalo kopala remizo. Razširili so vhod v jamo in vhodno pot, ki je prečkala naravni most, nad reko so zgradili razgledno ploščad ter tako turistom omogočili pogled na podzemno Pivko. Kar 30 ton cementa in 4,5 tone železa so porabili za izgradnjo novega železobetonskega mostu, postavili pa so tudi 408 m novih ograj. Kot rečeno, so vsa dela v jami potekala po načrtih I. A. Perka, dokončana pa so bila brez najmanjše nesreče, ob tem, da so obiski v jamo nemoteno potekali.

$\mathrm{V}$ tem času je bila na novo urejena tudi ploščad pred vhodom v jamo. 27. marca 1925 je družba Orenstein \& Koppel iz svoje tovarne v Nordhausnu poslala novo ("Montania", S-10, št. 
2044), močnejšo, prav tako bencinsko lokomotivo, ki pa je bila za razliko od prve dvoosne, triosna. Kupili so tudi lokomotivi pripadajoče šest sedežne vagončke s premičnimi naslonjali. Dobro leto kasneje, julija 1926, so pri jami kupili še tretjo, v Milanu izdelano bencinsko lokomotivo (Cemsa, tip $20 \mathrm{G}$, št. 20-779) z močjo 20HP. Dnevno so tako trije vlaki s skupno 31 vagončki popeljali turiste $\mathrm{v}$ jamo osemkrat.

Leta 1928 se je z dograditvijo vhodne ploščadi ter upravne zgradbe z železniško postajo in recepcijo podoba pred vhodom v jamo zadnjič bistveno spremenila. Po načrtih arhitekta Pietra Palumba je gradbeno podjetje Ghira e Pollaco iz Trsta zgradilo poslopje, ki se je lahko poleg že omenjene postaje in recepcije pohvalilo tudi z restavracijo. Nova, obiskovalcem prijaznejša, z dvema tiroma in dvignjenim peronom opremljena (varnejši in udobnejši dostop v jamo) železniška postaja, se je nahajala med upravnim poslopjem in "živo skalo". Tu so na vlak vstopali obiskovalci, ki so si jamo želeli ogledati tudi z železnico, medtem ko so tisti, ki so si jamo ogledovali peš, vstopali skozi glavni vhod. Do leta 1963 je veljal režim obiskov (ogled z vlakom in peš ali samo peš), ki je bil uveden skupaj z motorno železnico, po omenjenem letu pa so se morali vsi obiskovalci posluževati jamskega vlaka.

$\mathrm{V}$ petdesetih letih 20. stoletja je dotedanja organizacija prevoza v jamo že težko dohajala potrebe sodobnega turizma. Poleg tega so izpušni plini iz lokomotiv jamo močno zameglili, manjša je bila vidljivost, neprijeten pa je bil tudi smrad po izgorelih plinih. 6. aprila 1957 so pri Postojnski jami ob priliki slavnostne otvoritve turistične sezone stare dotrajane lokomotive zamenjali z dvema novima, akumulatorskima ("Emam” Segrate Milano, T 50). Izolirano in popolnoma suho polnilnico za akumulatorje so naredili v rovu, ki so ga med leti 1819 - 1866 uporabljali kot vhod v jamo. Leta 1964, do takrat so kupili še dve lokomotivi, so trije jamski vlaki dnevno lahko prepeljati v jamo 2160 obiskovalcev. Enotirna železnica s samo dvema izogibališčema na celotni progi (ob tem, da je manever prepenjanja lokomotiv pod Kalvarijo trajal okoli 20 minut), ki je v jami dopuščala vožnjo le treh lokomotiv naenkrat, je postajala pravo ozko grlo. Zato so pri Zavodu Postojnska jama začeli razmišljati o možnosti pogostejših odhodov vlaka v jamo. Leta 1959 so pri Projektivnem ateljeju v Ljubljani naročili projekte za ureditev dvotirne krožne železnice ter projekt za izgradnjo remize. Projektanti so predvideli več možnih rešitev, vendar je imela prednost tista, ki je obiskovalčevemu pogledu najbolj približala posamezne predele jame, hkrati pa najmanj posegla v naravne privlačnosti. Aprila 1964 je bila izpeljana prva etapa dvotirne proge (skozi vso jamo do vznožja Kalvarije) leta 1968 pa je bila zaključena še druga faza - pentlja do Koncertne dvorane. Obiskovalci tu še danes vstopajo na vlak, ki jih odpelje na prosto. Danes, 130 let potem, ko so v jami z uvedbo dvosedežnih vozičkov, ki jih je potiskal jamski vodnik obiskovalcem olajšali sprehod skozi jamo, je v Postojnski jami obiskovalcem na voljo deset modernih akumulatorskih lokomotiv s šestimi vlakovnimi kompozicijami, moderna vstopna in izstopna postaja ter krožna proga, opremljeno z ustrezno signalizacijo. 